\title{
Complete Nucleotide Sequence Analysis of a Brazilian Dengue Virus Type 2 Strain
}

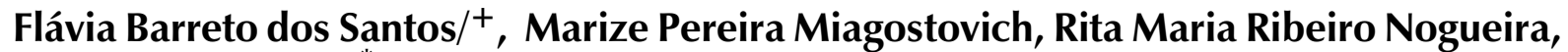 \\ Dianna Edgil ${ }^{*}$, Hermann Gonçalves Schatzmayr, Lee W Riley*, Eva Harris*
}

Departamento de Virologia, Instituto Oswaldo Cruz-Fiocruz, Av. Brasil 4365, 21045-900 Rio de Janeiro, RJ, Brasil *Division of Infectious Diseases, School of Public Health, University of California, Berkeley, CA, USA

In the last decade, dengue fever (DF) in Brazil has been recognized as an important public health problem, and an increasing number of dengue haemorrhagic fever $(D H F)$ cases have been reported since the introduction of dengue virus type 2 (DEN-2) into the country in 1990. In order to analyze the complete genome sequence of a DEN2 Brazilian strain (BR64022/98), we designed primers to amplify contiguous segments of approximately 500 base pairs across the entire sequence of the viral genome. Twenty fragments amplified by reverse transcriptase-PCR were cloned, and the complete nucleotide and the deduced amino acid sequences were determined. This constitutes the first complete genetic characterization of a DEN-2 strain from Brazil. All amino acid changes differentiating strains related to the Asian/American-Asian genotype were observed in BR64022/98, indicating the Asiatic origin of the strain.

Key words: dengue virus type 2 - complete genome - Brazil

Dengue (DEN) viruses are responsible for the most important arthropod-borne viral diseases in humans in terms of morbidity and mortality. Due to global population growth, increased urbanization, and the spread of both the mosquito vector and the four DEN serotypes, dengue is a major emerging problem in tropical and subtropical areas worldwide. Nowadays it is estimated that more than 100 million cases of dengue fever (DF) and 250,000 cases of the more severe form of the disease, dengue hemorrhagic fever/dengue shock syndrome (DHF/DSS), occur annually (Halstead 1997).

The four serotypes of DEN (DEN-1 to -4), genus Flavivirus (family Flaviviridae), consist of a singlestranded positive-sense RNA genome of approximately 10,700 bases in length, surrounded by a nucleocapsid and a lipid envelope containing the envelope and membrane proteins. The genome contains a single open reading frame that encodes three structural proteins designated $\mathrm{C}$ (core protein), M (membrane protein), and $\mathrm{E}$ (envelope protein) and seven nonstructural proteins (NS1, NS2A, NS2B, NS3, NS4A, NS4B and NS5), which is flanked by a 5' and a 3' nontranslated (NTR) region (Chambers et al. 1990, Lindenbach \& Rice 2001).

The partial sequencing of various regions of the DEN genome has been employed to determine the genetic variation of dengue viruses and to characterize genotypes

This work was supported by grants from the Fogarty International Center of the National Institutes of Health (TW00905), Conselho Nacional de Desenvolvimento Científico e Tecnológico (CNPq- 40.0164/98-1) and Fundação Oswaldo Cruz.

${ }^{+}$Corresponding author. Fax: + 55-21-2598.4373. E-mail: Flaviab2001@aol.com

Received 13 March 2002

Accepted 9 May 2002 within each serotype (Rico-Hesse 1990, Blok et al. 1991, Deubel et al. 1993, Lewis et al. 1993, Lanciotti et al. 1994, 1997, Chungue et al. 1995, Shurtleff et al. 2001). Genotypic characterization has been useful in molecular epidemiological studies that monitor the distribution of the circulating genotypes in endemic areas (Rico- Hesse et al. 1997, 1998, Messer et al. 2001).

Phylogenetic analysis of DEN-2 strains initially identified five genotypes, including two of Southeast Asian origin (Asian and American-Asian) (Rico-Hesse 1990, Lewis et al. 1993); further studies incorporating additional strains resulted in the merging of these two subgroups into one Asian/American-Asian genotype (Rico-Hesse et al. 1998). Detailed analysis of a 240-base pair (bp) sequence spanning the E/NS1 junction in a collection of Latin American strains showed that the Asian/American-Asian DEN-2 variant had been introduced into the Americas and had spread through the region over the past two decades, replacing the native American genotype (Rico-Hesse et al. 1997). This Asian/ American-Asian genotype has been associated with DHF cases, whereas the native American genotype has to date only been associated with classic DF. Recently, Leitmeyer et al. (1999) sequenced the full-length genome of DEN-2 viruses directly from viremic sera and identified nucleotide differences that consistently differentiated the Asian/ American-Asian DEN-2 viruses from the native American DEN-2 strains.

Since the introduction of DEN-2 into Brazil resulted in an increase in disease severity and in the number of epidemics (Nogueira et al. 1993, Zagne et al. 1994, Souza et al. 1995, Vasconcelos et al. 1995), we cloned and determined the complete nucleotide and the deduced amino acid sequences of a Brazilian DEN-2 strain isolated during an epidemic that occurred in 1998. This constitutes the first complete genetic characterization of a DEN-2 Brazilian strain since its introduction into the country in 1990 (Nogueira et al. 1990). 


\section{MATERIALS AND METHODS}

Viral strain - The DEN-2 strain analyzed in this study was obtained from the collection of the Flavivirus Laboratory, Department of Virology, Instituto Oswaldo Cruz-Fiocruz. The strain was isolated in 1998 from the serum of a DF patient by inoculation into Aedes albopictus C6/36 cell line (Igarashi 1985), and the serotype was identified by immunofluorescence using type-specific monoclonal antibodies (Gubler et al. 1984). The second passage was used for amplification, cloning and sequencing.

Primer design - Synthetic oligonucleotide primer pairs were designed to amplify overlapping fragments of approximately $500 \mathrm{bp}$ spanning the complete DEN-2 genome based on an alignment of the full-length sequences of representative Asian/American-Asian genotype DEN-2 strains. The sequences of the oligonucleotide primers used for the reverse transcriptasePCR (RT-PCR) are available upon request. The sequences of the strains Jamaica 1409/83 (accession no. M20558), New Guinea C/44 (AF038403), Thailand 16681/64 (U87411), and Thailand K10010/94 (AF100460) were retrieved from the National Center for Biomedical Investigation (NCBI) database, and the sequence alignments were generated using GeneJockey Software (Biosoft, Inc., Ferguson, MO).

RNA extraction and RT-PCR amplification - Viral RNA was extracted from the supernatant of infected cells, and fragments were amplified using a one-tube procedure according to Harris et al. (1998). The RT-PCR mixture contained $50 \mathrm{mM} \mathrm{KCl}, 10 \mathrm{mM}$ Tris (pH 8.5), $0.1 \%$ Triton $\mathrm{X}-100,0.01 \%$ gelatin, each of the four deoxynucleotide triphosphates at a concentration of $200 \mu \mathrm{M}, 1.5 \mathrm{mM}$ $\mathrm{MgCl}_{2}, 5 \mathrm{mM}$ dithiotreitol, each primer at a final concentration of $10 \mu \mathrm{M}, 0.025 \mathrm{U}$ of RAV-2 (Amershan Corporation, Arlington Heights, IL) and $0.025 \mathrm{U}$ of Taq DNA Polymerase (AmpliTaq, Perkin-Elmer Corporation, Foster City, CA) per ml of reaction. Five microliters of the extracted RNA were reverse transcribed at $42^{\circ} \mathrm{C}$ for 60 min, followed directly by 40 cycles of amplification consisting of $94^{\circ} \mathrm{C}$ for $30 \mathrm{sec}, 60^{\circ}-65^{\circ} \mathrm{C}$ for $1 \mathrm{~min}$, and $72^{\circ} \mathrm{C}$ for $2 \mathrm{~min}$, with a final extension at $72^{\circ} \mathrm{C}$ for $10 \mathrm{~min}$. Amplification was conducted using a Model 2400 thermal cycler (Perkin-Elmer, Norwalk, CT) or PTC-200-60 thermocycler (MJ Research, Inc., Watertown, MA). To sequence the DEN-2 virus genome, cDNA fragments amplified by PCR were cloned into TA vector pCR 2.1 (Invitrogen, San Diego, CA) according to the manufacturer's protocol. The sequence between genome positions 1 to 99 and 9974 to 10637 was determined by direct sequencing of the PCR product.

Sequencing of recombinant polypeptides clones Plasmids containing the recombinant DEN genes were sequenced in both directions using the BigDye Terminator Cycle Sequencing Ready Reaction kit (Applied Biosystems, Foster City, CA), 3.2 pmol of T7 forward (AATACGACTCACTATAG) and M13 Reverse (AACAGCTATGACCATG) primers combined with $0.5 \mu \mathrm{g}$ of plasmid DNA. Thermocycling conditions consisting of 25 cycles of $96^{\circ} \mathrm{C}$ for $30 \mathrm{~s}, 50^{\circ} \mathrm{C}$ for $1 \mathrm{~min}$ and $60^{\circ} \mathrm{C}$ for 4 min were used as recommended by the manufacturer.
After purification using $3 \mathrm{M}$ sodium acetate and $70 \%$ ethanol, the DNA was dried in a vacuum centrifuge. The pellet was resuspended in $20 \mu \mathrm{l}$ of template suppression reagent, heated for $2 \mathrm{~min}$ at $95^{\circ} \mathrm{C}$ and kept on ice until $10 \mu \mathrm{l}$ was loaded on an Applied Biosystems Prism 310 sequencer using perfomance-optimized polymer 6 (Applied Biosystems).

Sequence and phylogenetic analysis - The sequence analysis of the clones was performed by using GeneJockey Software (Biosoft, Inc.). Nucleotide and amino acid identity was determined using BLAST (http:// www.ncbi.nlm.nih.gov/Entrez/). Secondary structure predictions were performed using MFOLD (http:// bioinfo.math.rpi.edu/ mfold/rna/form1.cgi). Phylogenetic trees were constructed using PAUP* software (Sinauer Associates, Inc., Sunderland, MA) using the maximum parsimony algorithm, with a heuristic search and tree bisection-reconnection branch-swapping. Representative sequences from DEN serotypes 1, 3, and 4 were used as an outgroup to root the trees. The bootstrap method, with 100 replications, was used to estimate the reliability of the predicted trees.

\section{RESULTS}

To obtain the full-length sequence of a low-passage Brazilian DEN-2 strain, we designed primers to amplify contiguous segments across the entire sequence of the BR64022/98 virus genome. Twenty fragments obtained by RT-PCR were cloned into the TA vector and sequenced in both directions. The sequences between genome positions 1 and 99 (5'NTR) and 9,974 to 10,637 (3'NTR) were determined by directly sequencing the RT-PCR product in both directions. The complete sequence of BR64022/ 98 strain is 10,637 nucleotides long and was submitted to NCBI under accession number AF489932.

The overall homology at the nucleotide (nt) and amino acid (aa) level between the Brazilian strain and representatives of the Asian/American-Asian genotype and the native American genotype is shown in Table I. The Brazilian strain was most closely related to the AmericanAsian strains (98\% nt, $98 \%$ aa identity), followed by the Southeast Asian strains (92\% nt, 97\% aa), and finally the native American genotype ( $89 \%$ nt, $96 \%$ aa).

All amino acid changes reported to differentiate strains related to the Southeast Asian genotype from the native American genotype were observed in BR64022/98 (Table II), indicating the Asiatic origin of our strain. There were a number of additional nonconserved amino acid substitutions in the Brazilian strain relative to the Asian/American-Asian strain, notably charge reversals in E (K160E), NS4B (H88D), and NS5 (E558K) and charge additions in NS3 (G16E) and NS5 (G501E). The sequences of the 5' and 3' NTRs of the Brazilian strain, and thus the secondary structure predictions, are identical to those of the American-Asian viruses (e.g., Jamaican 1409/83 strain).

Figure shows the phylogenetic analysis performed using the maximum parsimony algorithm of BR64022/98 and full-length DEN-2 sequences retrieved from the NCBI database. The tree placed the Brazilian strain in the Ameri- 
TABLE I

Sequence identity between full-length dengue viruses type 2

\begin{tabular}{|c|c|c|c|c|c|c|c|c|}
\hline & $\begin{array}{c}\text { Brazil } \\
64022 / 98 \\
\end{array}$ & $\begin{array}{c}\text { Jamaica } \\
1409 / 83^{a}\end{array}$ & $\begin{array}{c}\text { Martinique } \\
703 / 98 \\
\end{array}$ & $\begin{array}{c}\text { New Guinea } \\
\text { C/44 }\end{array}$ & $\begin{array}{c}\text { Thailand } \\
16681 / 64\end{array}$ & $\begin{array}{c}\text { Thailand } \\
\text { K0010/94 }\end{array}$ & $\begin{array}{c}\text { Peru } \\
1797 / 95 \\
\end{array}$ & $\begin{array}{l}\text { Mexico } \\
0131 / 92 \\
\end{array}$ \\
\hline Brazil 64022/98 (AA) ${ }^{b}$ & - & $98^{c}$ & 98 & 97 & 97 & 97 & 96 & 96 \\
\hline Jamaica 1409/83 (AA) & $98^{d}$ & - & 98 & 98 & 97 & 97 & 96 & 96 \\
\hline Martinique 703/98 (AA) & 97 & 99 & - & 97 & 97 & 97 & 96 & 96 \\
\hline New Guinea C/44 (A) & 94 & 95 & 94 & - & 98 & 98 & 97 & 97 \\
\hline Thailand 16681/64 (A) & 93 & 94 & 93 & 97 & - & 98 & 97 & 97 \\
\hline Thailand K0010/94 (A) & 92 & 93 & 92 & 95 & 96 & - & 96 & 96 \\
\hline Peru 1797/95 (NA) & 89 & 90 & 89 & 91 & 90 & 90 & - & 99 \\
\hline Mexico 0131/92 (NA) & 89 & 90 & 89 & 91 & 90 & 89 & 97 & - \\
\hline
\end{tabular}

$a$ : NCBI accession numbers for the strains are M20558 for Jamaica 1409/83, AF208496 for Martinique 703/98, AF038403 for New Guinea C/44, U87411 for Thailand 16681/64, AF 100460 for Thailand K0010/94, AF100467 for Peru IQT1797/95, and AF100469 for Mexico 0131/92; $b$ : AA: American-Asian group of the Asian genotype, A: Southeast Asian group of the Asian genotype, NA: Native American genotype; $c$ : percentage amino acid identity (bold), as determined using BLAST; $d$ : percentage nucleotide identity, as determined using BLAST.

TABLE II

Nonconservative amino acid changes among dengue viruses type 2 strains found in the Americas

\begin{tabular}{lccccc}
\hline Gene & Position & $\begin{array}{c}\text { Peru } \\
1797 / 95\end{array}$ & $\begin{array}{c}\text { Brazil } \\
64022 / 98\end{array}$ & $\begin{array}{c}\text { Jamaica } \\
1409 / 83\end{array}$ & $\begin{array}{c}\text { Thailand } \\
\text { K0010/94 }\end{array}$ \\
\hline prM & 28 & $\mathrm{~K}$ & $E$ & $\mathrm{E}^{a}$ & $\mathrm{E}$ \\
& 31 & $\mathrm{~T}$ & $V$ & $\mathrm{~V}$ & $\mathrm{~V}$ \\
E & 160 & $\mathrm{~K}$ & $\mathbf{E}$ & $\mathrm{K}$ & $\mathrm{K}$ \\
& 390 & $\mathrm{D}$ & $N$ & $\mathrm{~N}$ & $\mathrm{~N}$ \\
NS1 & 128 & $\mathrm{~L}$ & $S$ & $\mathrm{~S}$ & $\mathrm{~S}$ \\
& 261 & $\mathrm{H}$ & $\mathbf{Y}$ & $\mathrm{H}$ & $\mathrm{H}$ \\
NS2A & 154 & $\mathrm{~L}$ & $\mathbf{S}$ & $\mathrm{L}$ & $\mathrm{L}$ \\
& 163 & $\mathrm{Q}$ & $\mathbf{L}$ & $\mathrm{Q}$ & $\mathrm{Q}$ \\
NS3 & 16 & $\mathrm{G}$ & $\mathbf{E}$ & $\mathrm{G}$ & $\mathrm{G}$ \\
& 567 & $\mathrm{~T}$ & $I$ & $\mathrm{I}$ & $\mathrm{I}$ \\
NS4B & 17 & $\mathrm{H}$ & $S$ & $\mathrm{~S}$ & $\mathrm{~S}$ \\
& 88 & $\mathrm{D}$ & $\mathbf{D}$ & $\mathrm{H}$ & $\mathrm{D}$ \\
NS5 & 23 & $\mathrm{~S}$ & $\mathbf{N}$ & $\mathrm{S}$ & $\mathrm{S}$ \\
& 271 & $\mathrm{~T}$ & $I$ & $\mathrm{I}$ & $\mathrm{I}$ \\
& 501 & $\mathrm{E}$ & $\mathbf{E}$ & $\mathrm{G}$ & $\mathrm{E}$ \\
& 558 & $\mathrm{~A}$ & $\mathbf{K}$ & $\mathrm{E}$ & $\mathrm{E}$ \\
& 645 & $\mathrm{D}$ & $N$ & $\mathrm{~N}$ & N \\
& 676 & $\mathrm{~K}$ & $S$ & $\mathrm{~S}$ & $\mathrm{~S}$ \\
& 800 & $\mathrm{~S}$ & $Q$ & $\mathrm{~K}$ & $\mathrm{~K}$ \\
& 819 & $\mathrm{~L}$ & $Q$ & $\mathrm{Q}$ & $\mathrm{Q}$ \\
\hline
\end{tabular}

$a$ : nonconservative amino acid changes identified in the dengue virus type 2 Brazilian strain BR64022/98 in relation to the American-Asian genotype, represented by Jamaica 1409/83, and the American genotype, represented by Peru IQT1797/95, according to their positions within the genes as indicated. Italics, amino acids associated with Asian/American-Asian genotype (15); bold, differences between the Brazilian strain and the Asian/ American-Asian genotype (Jamaica 1409/83).

can-Asian group of the DEN-2 Asian genotype, represented here by Jamaica 1409/83, Martinique 703/98, and Venezuela Mara4/90 strains. Similar phylogenetic trees were generated using maximum likelihood and neighbor joining algorithms (data not shown).

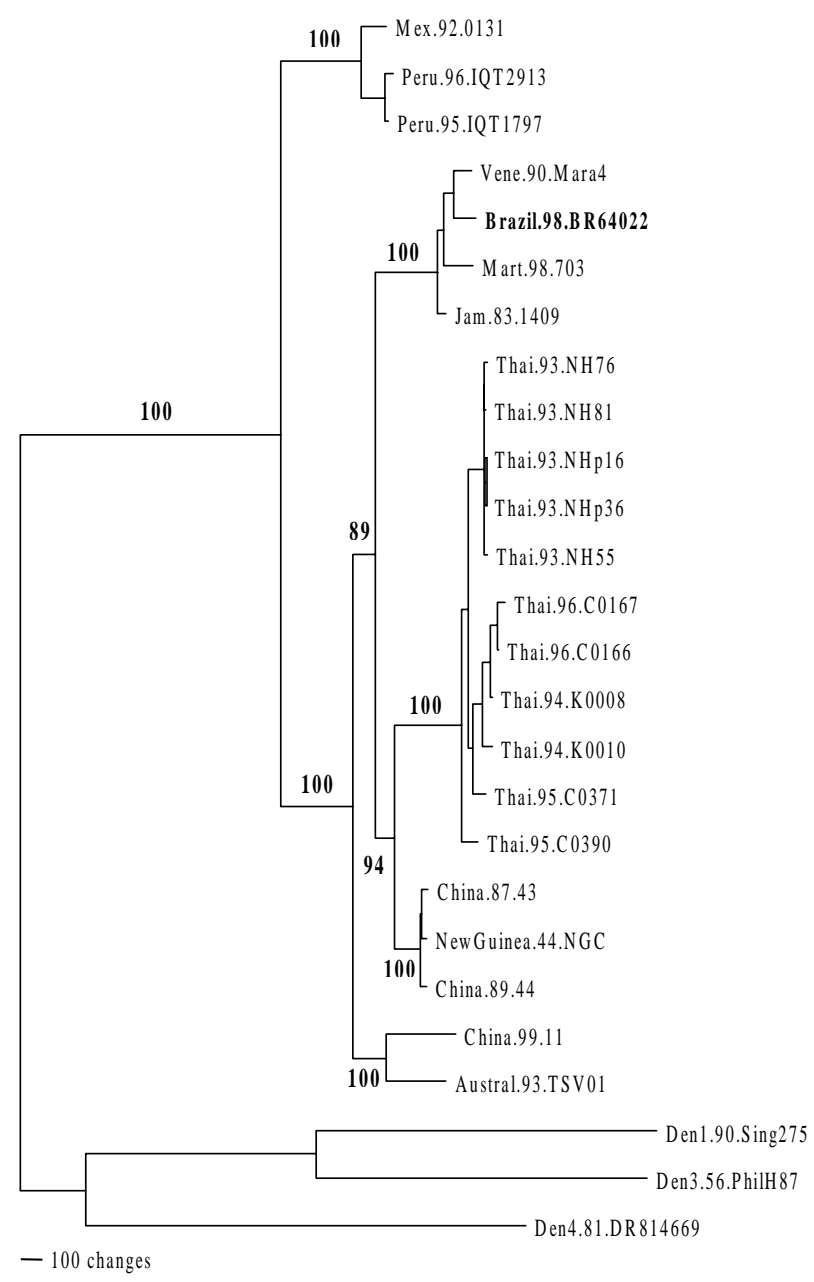

Phylogenetic analysis of full-length dengue virus type 2 (DEN-2) genomes. The complete nucletotide sequences of 24 representative DEN-2 strains were analyzed using the maximum parsimony algorithm and PAUP* software. Representative strains of DEN-1, DEN-3, and DEN-4 were used to root the tree. Each strain is abbreviated with the country of origin, followed by the year of isolation and the strain designation. Bootstrap values are indicated in bold at the branchpoints. 


\section{DISCUSSION}

Full-length analysis of the nucleotide and amino acids sequences of the Brazilian strain showed that it was more closely related to Asian/American-Asian DEN-2 genotype than to the native American DEN-2, confirming the Asiatic origin of the Brazilian strain. These data corroborate the results previously obtained by the partial sequencing of different genomic fragments (Deubel et al. 1993, RicoHesse et al. 1997, Miagostovich et al. 1998). A direct association between the introduction of Asian DEN-2 virus with severe disease in the Americas has been shown previously (Rico-Hesse et al. 1997), and our results are consistent with this scenario. The direction of transmission from Southeast Asia to the Americas has been demonstrated as well, since DEN-2 viruses from Brazil, Colombia, Mexico and Venezuela have a common progenitor with those from Southeast Asian (Rico-Hesse et al. 1997).

Comparing the complete genomic sequences of DEN2 strains from the native American and Asian genotypes, Leitmeyer et al. (1999) identified candidate nucleotide differences responsible for the virulent genotype. All the amino acids characteristic of the Asian genotype were identified in the Brazilian strain BR64022/98. These similarities with the Asian genotype were also reported recently for the Martinique 703/98 strain after analysis of the complete genome (Tolou et al. 2000). The Asianspecific non-conserved amino acid differences, as well as the additional differences specific to the Brazilian strain, are found in E, NS3, and NS5. Changes in E could affect immunogenicity or cell entry/tropism, whereas changes in NS3 (helicase/protease) and NS5 (RNA-dependent RNA polymerase) could affect replication efficiency. In addition, differences in the predicted secondary structure of the 5 , and 3' NTRs are found between the two genotypes; in these regions, the Brazilian isolate was identical to the American-Asian strains in sequence and consequently in the predicted secondary structures. The NTRs presumably mediate interaction with cellular and viral factors that regulate viral translation and RNA replication (Lindebach \& Rice 2001).

In Brazil, DEN-2 was introduced initially in the state of Rio de Janeiro in 1990, and after a short period of time, its presence was detected in 24 of 26 states (Nogueira et al. 1990, Ministry of Health, Brazil, http://www.funasa.gov.br). From 1986 to 2001, about 2,000,000 cases of DF were reported. DHF/DSS cases ( 928 to date) were only reported after the introduction of DEN-2 in 1990, when both DEN1 and DEN-2 co-circulated. The appearance of the first DHF/DSS cases and the increase in the number of hospitalizations resulting from DEN-2 secondary infection corroborate data that suggest an increase in virulence of this strain (Nogueira et al. 1990, 1993, Zagne et al. 1994, Rico-Hesse et al. 1997). Although secondary infection with a distinct serotype increases the risk of experiencing the severe form of the disease (Monath 1994, Halstead 1997), the intrinsic properties of dengue virus strains themselves are also important in determining the severity of the disease (Rosen 1977). Studies performed in Peru, where only the native American DEN-2 genotype circulates, showed that even with high secondary infection rates, no DHF/DSS cases were observed (Watts et al. 1999).

The partial sequencing of the junction from E/NS1 and analysis by restriction site specific-PCR of DEN-2 Brazilian strains from the latest epidemics (2000-2001) have shown that this Asian/American-Asian genotype is still the only one circulating in Brazil (data not published). Molecular epidemiological studies continue with strains isolated from both DF and DHF/DSS cases in order to detect the eventual introduction of a new DEN-2 genotype and evaluate its effect of the epidemiology of the disease.

\section{ACKNOWLEDGMENTS}

To Sangwei Lu for technical advice, Marcia Firmani and Josefina Coloma for assistance with sequencing, Karen Clyde for secondary structure predictions, and to Rebeca Rico-Hesse and Brian Brunelle for help with phylogenetic analysis.

\section{REFERENCES}

Blok J, Gibbs AJ, McWilliam SM, Vitaran UT 1991. NS1 gene sequences from eight dengue-2 viruses and their evolutionary relationships with other dengue-2 viruses. Arch Virol 118: 209-233.

Chambers TJ, Hahn CS, Galler R, Rice CM 1990. Flavivirus genome organization, expression, and replication. Annu Rev Microbiol 44: 649-688.

Chungue E, Cassar O, Drouet MT, Guzman MG, Laille M, Rosen L, Deubel V 1995. Molecular epidemiology of dengue1 and dengue-4 viruses. J Gen Virol 76: 1877-1884.

Deubel V, Nogueria RMR, Drouet MT, Zeller H, Reynes JM, Ha DQ 1993. Direct sequencing of genomic cDNA fragments amplified by the polymerase chain reaction for molecular epidemiology of dengue-2 viruses. Arch Virol 129: 197210.

Gubler DJ, Kuno G, Sather E, Valez M, Oliver A 1984. Mosquito cell cultures and specific monoclonal antibodies in surveillance for dengue viruses. Am J Trop Med Hyg 33: 158-165.

Halstead SB 1997. Epidemiology of dengue and dengue hemorrhagic fever. In DJ Gubler, G Kuno (eds), Dengue and Dengue Hemorrhagic Fever, CAB International, New York, p. 23-44.

Harris E, Roberts TG, Smith L, Selle J, Kramer LD, Valle S, Sandoval E, Balmaseda A 1998. Typing of dengue viruses in clinical specimens and mosquitoes by single-tube multiplex reverse transcriptase-PCR. J Clin Microbiol 36: 2634-2639.

Igarashi A 1985. Mosquito cell cultures and the study of arthropod-borne togaviruses. Adv Virus Res 3: 21-39.

Lanciotti RS, Gubler DJ, Trent DW 1997. Molecular evolution and phylogeny of dengue-4 viruses. J Gen Virol 78: 22792286.

Lanciotti RS, Lewis JG, Gubler DJ, Trent DW 1994. Molecular evolution and epidemiology of dengue-3 viruses. J Gen Virol 75: 65-75.

Leitmeyer KC, Vaughn DW, Watts DM, Salas R, Villalobos de Chacon I, Ramos C, Rico-Hesse R 1999. Dengue virus structural differences that correlate with pathogenesis. $J$ Virol 73: 4738-4747.

Lewis JG, Chang G-J, Lanciott, RS, Kinney RM, Mayer LM, Trent DW 1993. Phylogenetic relationships of dengue-2 viruses. Virology 197: 216-224.

Lindenbach BD, Rice CM 2001. Flaviviridae: the viruses and their replication. In DM Knipe, PM Howley (eds), Fields 
Virology, Lippincott Williams and Wilkins, Philadelphia, p. 991-1041.

Messer WB, Harris E, Gubler DJ, Sivananthan K, Preethimala LD, de Silva AM 2001. The molecular evolution and epidemiology of dengue 3, subtype III. Am J Trop Med Hyg 65: 282.

Miagostovich MP, Nogueira RMR, Schatzmayr HG, Lanciotti RS 1998. Molecular epidemiology of DEN-2 virus in Brazil. Mem Inst Oswaldo Cruz 93: 625-626.

Monath TP 1994. Dengue: the risk to developed and developing countries. Proc Natl Acad Sci USA 91: 2395-2400.

Nogueira RMR, Miagostovich MP, Lampe E, Schatzmayr HG 1990. Isolation of dengue virus type 2 in Rio de Janeiro. Mem Inst Oswaldo Cruz, 85: 253.

Nogueira RMR, Miagostovich MP, Lampe E, Souza RW, Zagne SMO, Schatzmayr HG 1993. Dengue epidemic in the state of Rio de Janeiro, Brazil, 1990-1: co-circulation of dengue 1 and dengue 2 serotypes. Epidemiol Infect 111: 163-170.

Rico-Hesse R 1990. Molecular evolution and distribution of dengue viruses type 1 and 2 in nature. Virology 174: 479493.

Rico-Hesse R, Harrison LM, Nisalak A, Vaughn DW, Kalayanarooj S, Green S, Rothman AL, Ennis FA 1998. Molecular evolution of dengue type 2 virus in Thailand. Am J Trop Med Hyg 58: 96-101.

Rico-Hesse R, Harrison LM, Salas RA, Tovar D, Nisalak A, Ramos C, Boshell J, de Mesa MT, Nogueira RM, da Rosa AT 1997. Origins of dengue type 2 viruses associated with increased pathogenicity in the Americas. Virology 230: 244251.
Rosen L 1977. The Emperor's New Clothes revisited, or reflections on the pathogenesis of dengue hemorrhagic fever. Am J Trop Med Hyg 26: 337-43.

Shurtleff AC, Beasley DWC, Chen JJY, Ni H, Suderman MT, Wang H, Xu R, Wang E, Weaver SC, Watts DM, Russell $\mathrm{KL}$, Barrett ADT 2001. Genetic variation in the 3' noncoding region of dengue viruses. Virology 281: 75-87.

Souza RV, Cunha RV, Miagostovich MP, Timbó MJ, Montenegro F, Pessoa ETFP, Nogueira RMR, Schatzmayr HG 1995. An outbreak of dengue virus infection in the State of Ceará, Brazil. Mem Inst Oswaldo Cruz 90: 345346.

Tolou H, Couissinier-Paris P, Mercier V, Pisano MR, De Lamballerie X, De Micco P, Durand JP 2000. Complete nucleotide sequence of dengue type 2 virus from the French West Indies. Biochem Biophys Res Commun 277: 89-92.

Vasconcelos PFC, Menezes DB, Melo LP, Paula Pessoa ETF, Rodrigues SG, Travassos Da Rosa ES, Timbó MJ, Coelho ICB, Montenegro F, Travassos da Rosa, JFS, Andrade FMO, Travassos da Rosa APA 1995. A large epidemic of dengue fever with dengue hemorrhagic cases in Ceará State, Brazil, 1994. Rev Inst Med Trop São Paulo 37: 252-255.

Watts DM, Porter KR, Putvatana P, Vazquez B, Calampa C, Hayes CG, Halstead SB 1999. Failure of secondary infection with American genotype dengue 2 to cause dengue haemorrhagic fever. Lancet 354: 1431-1434.

Zagne SMO, Alves VGF, Nogueira RMR, Miagostovich MP, Lampe E, Tavares W 1994. Dengue haemorrhagic fever in the state of Rio de Janeiro, Brazil: a study of 56 confirmed cases. Trans $R$ Soc Trop Med Hyg 88: 677-679. 
